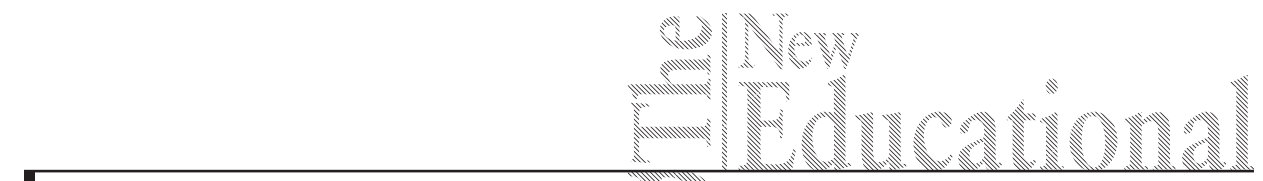

Triyanto, Rif'ati Dina Handayani

Indonesia

\title{
Teacher Motivation Based on Gender, Tenure and Level of Education
}

DOI: 10.15804/tner.2016.45.3.16

\begin{abstract}
Teacher motivation plays an important role in the success of education, which is influenced by many factors. Therefore, this article examines how gender, tenure, and level of education influence teacher motivation. Data were collected with the use of questionnaires of 135 Indonesian teacher respondents, in-dept interviews, and observations. Numeric data were analyzed by means of Statistical Package for the Social Sciences (SPSS analysis). The research showed that male teachers are more motivated than female teachers. Junior teachers have a higher motivation than senior teachers. Teachers with a bachelor's degree are more motivated than teachers with a master's degree.
\end{abstract}

Keywords: teacher motivation, gender, tenure, level of education

\section{Introduction}

Teachers play a crucial role in the success of every educational policy initiative, yet in the most parts of the world, they are poorly motivated and have low identity (Agezo, 2010; Cogneau, 2003; Ololube, 2006). Teachers can engage in many metacognitive and cognitive activities that are relevant to guiding students' learning (Duffy et al., 2009). Studies show that improvement in teacher motivation has benefits for students as well as for teachers themselves. Dolton and Marcenaro (2011) observe that countries with poor records of teacher motivation have low teacher performance leading to poor educational outcomes. Teachers deal with 
many ethical problems in their practice, they encounter issues such as inappropriate allocation of resources, the situations in which pupils are being discussed inappropriately, and irresponsible colleagues (Husu et al., 2007; Shapira et al., 2009).

Motivation may mean different things to different people. Velez (2007) conceptualizes motivation as an inspiration or encouragement of a person to do his or her best. Snowman et al. (2008) define motivation as the forces that lead to the arousal, selection, direction, and continuation of behavior, where teacher motivation is a concept that assists us in understanding why teachers behave the way they do. Motivation is the "internal desires for personal and professional development and working in educational settings" (Claeys, 2011, p.4; Bennell and Akyeampong, 2007). Teacher motivation for work can be interpreted as a mental boost in the teacher to do his/her job.

Bennell (2004) says that teacher motivation is similar to all the psychological processes that influence teachers' behavior towards the achievement of educational goals and yet these psychological processes cannot be observed directly due to many organizational and environmental challenges that affect the achievement of educational goals. High levels of job dissatisfaction, stress, and burnout can negatively influence motivation, cognition, and job performance (Dai et al., 2004).

In Indonesia, carrying out their tasks in a professional way, teachers are obliged to develop the learning plan, implement quality teaching, as well as assess and evaluate learning outcomes. Sardiman (2011) says that the teacher plays many different roles, e.g., of an informant, organizer, motivator, initiator, transmitter, facilitator, mediator, and assessor. It can be seen that the teacher adopts many roles that must be played simultaneously. The teacher in at-risk conditions can re-motivate himself with three principles-managing emotion counters: emotional exhaustion, joining communities' counters depersonalization, and boosting efficacy counters in case of low personal accomplishment (Falout, 2010). Dörnyei (2005) emphasized how substantially teacher motivation influences student motivation and learning achievement.

Indonesia is working hard to improve the quality of teaching. Teacher competence test held by the Ministry of Education in 2015 reported that thte average teacher score was 48.94. This score was under the minimum score of 55 (scale 100). It indicates that teacher motivation is still at a low level. There are many factors that influence teacher motivation. The research analyzed three factors: gender, tenure, and level of education. Bugler, McGeown and St Clair-Thomson (2015) reported that academic motivation is influenced by gender. Tenure also affects academic assesment (Filetti, Wright, \& King, 2010). The level of education 
holds a great promise for improving teachers' professional motivation (Iliya, \& Ifeoma, 2015). Therefore, this article examines how gender, tenure, and level of education influence teacher motivation.

\section{Research Problem}

The problem of this research is the effect of teacher motivation.

\section{Research Focus}

The focus of this research is to assess the factors of gender, tenure, and level of education influencing teacher motivation.

\section{Research Methodology}

\section{Research General Background}

There are two main factors affecting teacher motivation, namely extrinsic and intrinsic factors. Intrinsic factors are those which come from within a person, whereas extrinsic motivation factors are those which are determined basically by the level and type of external rewards that are available (Bennell and Akyeampong, 2007). Johnson et al. (2005), Salifu et al. (2013) point out that the extrinsic factors affecting teacher motivation are many categories, namely: attractive remuneration, student discipline, good working conditions, favorable educational policies and high occupational status.

\section{Research Sample}

The sample of this research consisted of 135 teachers ( 75 females, 60 males) in 20 Surakarta School (junior high school). The teachers participating in this study work in schools varying in size, type (state school/religious state school), level of education (Bachelor's and Master's), and the teachers' age ranged from 23 to 55. In addition, the teachers were from different fields of science and the average teaching experience was 20.54 years $(S D=10.51) .16$ teachers were interviewed and observed to validate the data. 


\section{Instrument and Procedures}

Numeric data were collected using a questionnaire regarding the teachers' motivation in performing their professional duties, which consisted of 15 questions, namely: completion of teaching according to the syllabus, doing the work not only for its own sake, carrying out the assigned tasks, solving problems as well as possible, trying to improve competence and knowledge, developing teaching methods, presenting work on time, starting classes on time, following the activities of others in a timely manner, obeying all the rules, obeying the instruction leadership, carrying out duties in accordance with procedures, establishing good relationships with colleagues, helping other teachers experiencing difficulties, and expressing criticism for the good of the institution. The questionnaire provided four kinds of options, i.e.: always (4), frequently (3), sometimes (2), and never (1). In-depth interviews and observations were carried out based on the questionnaire to strengthen and validate the findings.

\section{Data Analysis}

Numeric data were analyzed by means of Statistical Package for the Social Sciences (SPSS analysis). In the research, SPSS was used to assess the extent of teacher motivation in carrying out duties as professionals. Based on the analysis of data obtained from the 15 motivation indicators, it was found that there were 10 valid and 5 invalid indicators, because the meaning of the last was below 0.3338 ( $\mathrm{N}$ =135), namely completion of teaching according to the syllabus, presenting work on time, starting classes on time, following the activities of others in a timely manner, obeying the instruction leadership. Based on reliability analysis, 10 indicators of motivation were included in the overall validation of reliable criteria with the value of Cronbach's alpha $=0.822$. The hypotheses of the study were formulated as follows:

H1: Motivation between male and female teachers will differ significantly.

$\mathrm{H} 2$ : Motivation between senior and junior teachers will differ significantly.

H3: Motivation between bachelor and master degree teachers will differ significantly.

The SPSS analysis was validated and strengthened by interactive data analysis of Miles \& Huberman (1984). Interactive data analysis consists of four cycle steps: data collection, data reduction, data display, and conclusions. Data collection was 
carried out by interviews and observation of the teachers. Data reduction was the process of selecting, focusing, simplifying, abstracting, and transforming the 'raw' data that appeared in written-up field notes. Data reduction was done continuously throughout any qualitatively-oriented project. Data reduction was part of analysis. The 'display' was an organized assembly of information that allowed for conclusion drawing and action. The last step of the analysis activity was conclusion drawing and verification.

\section{Research Results}

Results showed that teacher motivation was very high (84.93\%), with an average value of 3.971 ( $\mathrm{SD}=0.32402$ ). Table 1 shows a comparison of means of 10 motivation indicators, where establishing good relationships with colleagues is the highest indicator and expressing criticism for the good of the institution scores the smallest value.

Table 1. Teacher motivation in each criterion

\begin{tabular}{lccc}
\hline & Mean & Std. Dev & Std. Error Mean \\
\hline Doing the work not only for its own sake & 3.49 & .507 & .086 \\
\hline Carrying out the assigned tasks & 3.80 & .406 & .069 \\
\hline Solving problems as well as possible & 3.51 & .507 & .086 \\
\hline Trying to improve competence and knowledge & 3.40 & .604 & .102 \\
\hline Developing teaching methods & 2.74 & .443 & .075 \\
\hline Obeying all the rules & 3.69 & .530 & .090 \\
\hline Carrying out duties in accordance with procedures & 3.74 & .443 & .075 \\
\hline Establishing good relationships with colleagues & 3.83 & .382 & .065 \\
\hline Helping other teachers experiencing difficulties & 3.11 & .583 & .098 \\
\hline Expressing criticism for the good of the institution & 2.66 & .725 & .123 \\
\hline
\end{tabular}

Table 2. Teacher motivation based on gender

\begin{tabular}{cccccc}
\hline & Gender & $\mathrm{N}$ & Mean & Std. Dev & Std. Error Mean \\
\hline Motivation & $\mathrm{M}$ & 60 & 3.4625 & .25788 & .06447 \\
\hline $\mathrm{F}$ & 75 & 3.3421 & .36865 & .08458 \\
\hline
\end{tabular}

Table 2 presents teacher motivation based on gender, where the average values of the male teachers' motivation are higher than those of the female teachers. Interviews showed that the female teachers had undertaken the job only to help 
their husbands to meet the needs of their families. Therefore, the female teachers' motivation is lower than the male teachers'. In contrast, the male teachers consider themselves as the leader of their families so they need to increase their motivation to make a better career.

Analysis of the teachers' motivation based on the average number of years in the teaching profession is shown in Table 3 . The average number of years in the teaching profession is divided into two parts: $\geq 25$ years (senior teachers) and $<$ 25 years (junior teachers). The results showed that the motivation value of the teachers with tenure $\geq 25$ years was smaller than that of the teachers working < 25 years.

Table 3. Teacher motivation based on tenure ( $\geq 25$ years and $<25$ years)

\begin{tabular}{cccccc}
\hline & Tenure & $\mathrm{N}$ & Mean & Std. Deviation & Std. Error Mean \\
\hline \multirow{3}{*}{ Motivation } & $\geq 25$ & 83 & 3.3000 & .35949 & .09608 \\
\cline { 2 - 6 } & $<25$ & 52 & 3.4619 & .28892 & .06305 \\
\hline
\end{tabular}

Interviews and observations showed that the senior teachers, with tenure more than 25 years, had decreased motivation. Senior teachers generally have less passion in following various capacity building activities. Even some teachers prefer to wait for retirement rather than joining capacity building. In contrast, the teachers with tenure of less than 25 years have higher motivation. They have greater hope and motivation to improve their careers.

Table 4 shows the teachers' motivation based on education, where the average motivation of the teachers with undergraduate education is higher than that of the teachers with a master's degree. This is a unique finding. The teachers with a bachelor's degree have higher motivation than the teachers holding a master's degree. Observations show that the teachers with a master's degree generally feel that they have enough knowledge, so they feel no need to follow the capacity building program.

Table 4. Teacher motivation based on education

\begin{tabular}{clcccc}
\hline & Education & $\mathrm{N}$ & Mean & Std. Devn. & Std. Error Mean \\
\hline Motivation & Bachelor's & 102 & 3.4138 & .26420 & .04906 \\
\hline & Master's & 33 & 3.3167 & .56006 & .22864 \\
\hline
\end{tabular}




\section{Discussion}

Results of the research on the motivation of junior high school teachers in the city of Surakarta showed that the average number of teachers is motivated in carrying out their duties as professionals. This can be explained by the fact that teachers feel a huge responsibility towards their job. Besides, concern for young people is also a factor that affects the intrinsic motivation of teachers, such as a sense of love towards children, aspiration to contribute to citizens. William and Forgasz (2009) concluded that factors such as a desire to work with children, the desire to contribute to society, and the belief in possession of teacher attributes were more important than extrinsic factors in the participants' decision to become teachers. Furthermore, Chaterine (2008) found that altruistic factors such as the desire to work with children, provision of intellectual stimulation by teaching, "calling" to teach, love of teaching, perceived easy nature of teaching work, and the desire for a career change were responsible for the participants' motivation in their teaching profession.

Results of the analysis also showed that the indicator of motivation that has the greatest value is to maintain good relationships with colleagues. This suggests that a conducive work environment strongly supports the activities of teachers in schools. Salifu (2013) states that teachers' working conditions may be explained as the needed atmosphere created for teachers in the work place to motivate them to better performance. When teachers have conducive working environments such as light workload in terms of class size and number of teaching hours, good relationships among themselves and with students and good leadership from principals, they are likely to be motivated and have job satisfaction (Adelabu, 2005; Bennell, 2004; Mathew, 2005). Teachers can collaborate to mentor each other, modeling the behaviors and values that lead to professional success (Hooker, et al., 2003; Park, et al., 2007). Maintaining good relationships with colleagues is also a form of ethical knowledge of the teacher.

Ethical knowledge is about an introduction into values and morality, to give teachers an understanding of how to relate to other people, together with the ability to apply the values and rules intelligently (Aspin, 2000; Thornberg, 2008). According to Taylor (1994), ethical knowledge may encourage exploration of choices and commitment to responsibilities and develop value preferences and an orientation to guide attitudes and behavior. A mutual goal can simply mean enjoying a pleasant day, with daily greetings, respectful language, and polite demeanor contributing immensely toward a cooperative environment (Falout, 2010). 
Indicators of expressing criticism have the smallest average value because teachers sometimes feel awkward or embarrassed to give feedback or express criticism of the institution. The teachers who participated in this study worked in the city of Surakarta, they had a culture that was very smooth. Javanese people are very delicate, gentle, and humble, not seeking conflict. They believe that expressing criticism of a person or institution requires consideration, adopting language that does not hurt the receiver's feelings. Budi (2011) states that the dominant character that is positive is that Javanese people's actions tend to be smooth, using "unggah - ungguh" (manners), based on the spirit of brotherhood and tolerance,as described in the proverb "tepo seliro"(mutual respect) and the Javanese like stating everything in an indirect manner, as revealed by the proverb: "wong Jowo ngone semu, sinamun ing samudana, sesadane ingadu manis" (Javanese tend to be veiled, full of symbols). That is why the indicator of the motivation of teachers to express criticism has the smallest value.

Based on gender, the average value of the male teachers' motivation is higher than that of the female teachers. This is understandable because men have a tendency to be more active than women. In women's own culture it is still considered positive not to have motivation. As in the division of gender roles, girls are focused more on the domestic, reproductive, feminine roles and if they do professional work, they are not the main breadwinner, but a secondary earner, while boys are concentrated on the productive, public, masculine roles and being the main breadwinner (Fakih, 1997). According Purwadi (2000:147), the image of a woman is not only shaped by the views of the local culture, but also by the views based on the doctrine of Christian theology, especially according to textual understanding. Women report lower overall levels of satisfaction. If women have bigger responsibility at home, this may also contribute to decreased levels of job satisfaction for those who bear the dual pressure of home and work (Bishay, 1996). In contrast, research findings (Ghana National Association of Teachers \& Teachers and Education Workers Union of Trade Union Congress, 2009; Smithers \& Robinson, 2003) show that females are more likely to be intrinsically motivated to stay in the profession than men.

Considering teacher motivation based on years of work in the teaching profession, junior teachers are more motivated than senior teachers because junior teachers are still eager and their knowledge is still new comparing to senior teachers. Junior teachers always try to show their ability in developing teaching methods in class or express constructive criticism of the institution. The overall motivation indicator shows that the average score of the young teachers is higher than that of the senior teachers. Lindeman (Knowles, 1990) revealed that young 
adults are always motivated to learn in accordance with the need for experience and interests that learning will be satisfying so that they begin to organize learning activities. In accordance with a study conducted in the United States, Johnson et al. (2005) state that younger teachers, especially those under thirty, are least likely to remain in their schools.

When considering teacher motivation from the point of view of education, the teachers in the city Surakarta with a master's degree have higher motivation than the teachers with a bachelor's degree. The cause is a mismatch between what they think and reality. Michelowa (2002) is of the opinion that teachers with a very high educational attainment are generally less satisfied and less motivated in their job and prefer to leave. As she observed, "teachers with a high level of education face a mismatch between their professional expectation and reality".

\section{Conclusions}

Based on the results of this study, the teachers' motivation is very high in Surakarta City, Indonesia, where the male teachers are more motivated than the female teachers. Moreover, junior teachers have higher motivation than senior teachers and teachers with a bachelor's degree are more motivated in carrying out their professional duties than those with a master's degree.

\section{References}

Agezo, K.C. (2010). Why teachers leave teaching: The case of pre-tertiary institutions in Ghana. International Journal of Education Reform, 19(1), 51-52.

Aspin, D. (2000). A clarification of some key terms in values discussions. In M. Leicester, C. Modgil, \& S. Modgil (Eds.), Moral education and pluralism: Education, culture and values, vol. 4 (pp. 171-180). London: Farmer Press.

Bennell, P. (2004). Teacher motivation and incentives in sub - Saharan Africa and Asia: Knowledge and Skills for Development. Brighton.

Bennell, P., \& Akyeampong, K. (2007). Teacher motivation in Sub-Saharan Africa and South Asia: Department for International Development.

Bishay, A. (1996). Teacher motivation and job satisfaction: a study employing the experience sampling method. Journal Undergraduate Science: 147-154.

Budi I,. S, (2011), Laku Prihatin Investasi menuju Sukses Ala Manusia Jawa. Yogyakarta : Memayu publishing.

Bugler, ; McGeown, S.P. \& St Clair-Thompson, H (2015). Gender Differences in Adoles- 
cents' Academic Motivation and Classroom Behaviour, Educational Psychology, v35 n5 p541-556

Catherine, S. (2008). Initial and changing student teacher motivation and commitment to teaching. Asia-Pacific Journal of Teacher Education, 36 (2), 79-104.

Claeys, L. (2011). Teacher motivation to teach and to remain teaching culturally and linguistically diverse students. Doctor of Philosophy in Education and Human Development Bicultural-Bilingual Studies, The University of Texas at San Antonio, Texas.

Cogneau, D. (2003). Colonization, school and development in Africa: An empirical analysis. DIAL working Paper. from http://ideas.repec.org/p/dia/wpaper/dt200301.html.

Dai, D.Y., \& Sternberg, R.J. (2004). Motivation, emotion, and cognition: integrative perspectives on intellectual functioning and development. Mahwah, NJ: Erlbaum.

Dolton, P., \& Marcenaro-Gutierrez, O.D. (2011). If you pay peanuts do you get monkeys? A cross-country analysis of teacher pay and pupil performance. Economic Policy, 26(55), 5-55.

Dörnyei, Z. (2005). The psychology of the Language learner: individual differences in second language acquisition. Mahwah, New Jersey: Erlbaum.

Duffy, G.G, Miller S. Parsons S \& Meloth M. (2009). Teacher as metacognitive professionals. In D.J. Dunlosky, \& A.C. Graesser (Eds.). Handbook of Metacognition in Education (pp. 240-256). New York, NY: Routledge.

Fakih, M. (1997). Menggeser Konsepsi Gender dan Transformasi Sosial. Yogyakarta: Pustaka Pelajar.

Falout, J. (2010). Strategies for teaching motivation. The Language Teacher Online; from jalt-publications.org/tlt.

Filetti, J; Wright, M \& ; King, W.M. (2010). Grades and Ranking: When Tenure Affects Assessment, Practical Assessment, Research \& Evaluation, v15 n14 Oct 2010

Ghana National Association of Teachers, \& Teachers and Education Workers Union of Trade Union Congress. (2009). Results of a questionnaire survey 2009. Ghana

Hooker, C., Nakamura, J., \& Csikszentmihalyi, M. (2003). The group as mentor: Social capital and the systems model of creativity. In P.B. Paulus \& B.A. Nijstad (Eds.), Group creativity: Innovation through collaboration (pp. 225-244). New York: Oxford University Press.

Husu, J., \& Tirru, K. (2007). Developing whole school pedagogical values-a case of going through the ethos of "good schooling". Teaching and Teacher Education, 23, 390-401.

Iliya, A \& Ifeoma, L.G. (2015). Assessment of Teacher Motivation Approaches in the Less Developed Countries, Journal of Education and Practice, v6 n22 p10-17.

Johnson, S.M., Berg, J.H., \& Donaldson, M.L. (2005). Who stays in teaching and why: A review of the literature on teacher retention. The Project on the next generation of teachers: Harvard Graduate School of Education.

Knowles, M. (1990). Adult Learner: A Neglected Species. Houston : Gulf Publishing Company.

Mathew, L.J. (2005). The impact of higher salaries and performance-related pay on reten- 
tion rate of graduate teachers of public schools in Singapore. Faculty of Education. Monash University.

Michaelowa, K. (2002). Teacher job satisfaction, student achievement and the cost of primary education in Francophone Sub - Saharan Africa. Paper presented at the Hamburgischer Welt-Wirtschafts Archiv(HWWA) discussion paper 188, Hamburge Institute of International Economics.

Miles, M.B. and Huberman, A.M. (1984). Qualitative Data Analysis, A Sourcebook of New Methods. Beverly Hills CA: Sage Publications Inc.

Ololube, N.P. (2006). Teachers' job satisfaction and motivation for school effectiveness: An assessment. Essays in Education, 18(1-19).

Park, S., Oliver, J.S., Johnson, T.S., Graham, P., \& Oppong, N.K. (2007). Colleagues' roles in the professional development of teachers: Results from a research study of National Board certification. Teaching and Teacher Education, 23(4), 368-389.

Purwadi, A. (2000). Islam dan Problem Gender: Telaah Kepemimpinan Wanita Dalam Perspektif Tarjih Muhammadiyah. Yogyakarta: AdityaMedia.

Salif, I and Agrebenyega J,S. (2013). Teacher motivation and identity formation; issues affecting professional practice. MIER Journal of Educational Studies, Trends \& Practices, Vol.3 No.1 pp.58-74.

Sardiman. (2011). Interaksi dan motivasi belajar mengajar. Jakarta: Rajawali Press

Shapira-Lishchinsky,O., \& Orland - Barak, L. (2009). Ethical dilemmas in teaching: the Israeli case. Education and Society, 27(3). 27-34.

Snowman, J., Mcown, R., \& Biehler, R. (2008). Psychology Applied to Teaching (13 rd.). USA: Houghton Mifflin.

Taylor, M. (1994). Overview of values education in 26 European countries. In M. Taylor (Ed.), Values education in Europe: A comparative overview of a survey of 26 countries in 1993 (pp. 1-66). Dundee: Scottish Consultative Council on Curriculum.

Thornberg, R. (2008). The lack of professional knowledge in values education. Teaching and Teacher Education, 24, 1791-1798.

Williams, J., \& Forgasz, H. (2009). The motivations of career change students in teacher education. Asia-Pacific Journal of Teacher Education, 37(1), 95-108. 